\title{
The Efficacy of Erbium Laser in Infected Root Canals: ex vivo study
}

\author{
Agime Dragidella, Msc \\ Faculty of Medicine Prishtina, Prishtina, Kosovo \\ Mira Jankullovska, PhD \\ Faculty of Medicine Skopje, Skopje, Macedonia \\ Xhevdet Aliu, PhD \\ Faculty of Medicine Prishtina, Prishtina, Kosovo \\ David Stubljar, BSc \\ In-Medico, Metlika, Slovenia
}

Doi: 10.19044/esj.2017.v13n30p453 URL:http://dx.doi.org/10.19044/esj.2017.v13n30p453

\begin{abstract}
Background: Golden standard of cleaning infected root canals with irrigants does not completely remove pathogens. The aim of our study was to estimate efficacy of Er:YAG laser compared to standard irrigation with $\mathrm{NaOCl}$ in infected root canals. Methods: 140 extracted premolar singlerooted teeth were used. The crowns were cut off so that we obtained $15 \mathrm{~mm}$ of root canal. Samples were divided into four groups and inoculated with Enterococcus faecalis, Candida albicans, Streptococcus sanguinis, Fusobacterium nucleatum. As disinfecting methods we performed Er:YAG laser radiation and irrigation with $5.20 \% \mathrm{NaOCl}$. Viability of microorganisms was analyzed using fluorescence by flow cytometry. Results: Both methods effectively eliminated major percent of microorganisms. Statistical differences were observed between tested organisms ( $\mathrm{p}<0.05)$ for Er:YAG laser (30 and 90 seconds) and $5.20 \% \mathrm{NaOCl}$ irrigation. The number of dead microorganisms was significantly higher for $C$. albicans and $S$. sanguinis than for $E$. faecalis or $F$. nucleatum. Longer duration of laser radiation of 90 seconds showed significant efficiency compared to 30 -seconds radiation $(\mathrm{p}<0.001)$ and achieved over $80 \%$ of dead microbial cells. Disinfecting activity was even better in combination with irrigants and achieved over $90 \%$ in addition of $\mathrm{NaOCl}$. Conclusions: Irradiation with Er:YAG laser could be used as a simple and standard disinfection method in endodontics, or even better can be used as as adjuvant therapy to standard and irrigation treatment.
\end{abstract}


Keywords: Root canal disinfection, Er:YAG, endodontic irrigants, $\mathrm{NaOCl}$

\section{Introduction}

Complex structure of root canal system presents a major challenge in the elimination of pathogenic microorganisms during endodontic cleaning processes and enables resistance to irrigation of root canals ( $\mathrm{Ng}$ et al., 2011). Although irrigation with $\mathrm{NaOCl}$ removes the majority of microorganisms, it is still possible that microbes resist due to smear layers that reduce effectiveness of irrigants (Soukos et al., 2006). Chelator substances that remove smear layer are usually used enhanced methods of irrigation (Gründling et al., 2011).

In addition, various lasers are available as modern methods, which are performed in periodontology and endodontics. Er:YAG lasers were evaluated as effective in removing residuals and smear layers (Schwarz et al, 2008; Aoki et al., 2000; Ishikawa et al., 2004). Moreover, Er:YAG radiation led to clinical improvements after root canal infection, and performed similar to ultrasonic debridement (Sculean et al. 2004). Antimicrobial effect on Enterococcus faecalis biofilms in root canals proved significant compared to irrigation (De Meyer et al., 2016; Zehnder, 2006).

The aims of study were to check the efficiency of Er:YAG laser as method for treatment of infected root canal, and compare the effectiveness to standard irrigant $\mathrm{NaOCl}$.

\section{Materials and Methods}

Samples

Finally, 140 extracted single-rooted teeth were included. The crown of each tooth was cut off using a diamond blade Isomet 1000 (Buehler $\mathrm{GmbH}$, Germany) to obtain $15 \mathrm{~mm}$ long root canal. The canals were then enlarged to a size of \#35 using Protaper files (Maillefer Instruments, Switzerland). Between each filling, irrigation with $2.5 \% \mathrm{NaOCl}$ was performed. Teeth were then rinsed with 17\% EDTA and sterilized. Sterilization was microbiologically tested on blood agar for $24 \mathrm{~h}$ at $37{ }^{\circ} \mathrm{C}$. The teeth were proceeded when no bacterial contamination was observed on blood agar plates.

Teeth were divided into 4 groups and inoculated with Enterococcus faecalis, Candida albicans, Streptococcus sanguinis, Fusobacterium nucleatum. The major groups were further divided into subgroups due to the disinfecting method; Er:YAG laser radiation, irrigation with $\mathrm{NaOCl}$, and combination of Er:YAG laser and $\mathrm{NaOCl}$, positive control, negative control) 


\section{Bacterial biofilm}

Strains of microorganisms were inoculated on the blood agar plates and incubated for 24 hours in an anaerobic atmosphere at $37^{\circ} \mathrm{C}$. After successful microbial growth on blood agar plates, bacterial suspensions of 5 McFarlands $\left(1.5 \times 10^{9}\right.$ cells $\left./ \mathrm{mL}\right)$ in the thioglycolate (TIO) broth for each bacterial strain were prepared. The concentrations were measured by spectrophotometer. Root canals were then inoculated with the suspension and incubated for 7 days at $37^{\circ} \mathrm{C}$ in an anaerobic atmosphere. Every day 30 $\mu \mathrm{L}$ of fresh $5 \mathrm{McFarland}$ microbial suspension in TIO broth was added.

The growth of biofilm in root canals was confirmed with bacterial cultivation on agar plates and by flow cytometry. Root canals were rinsed with $1 \mathrm{X}$ phosphate buffer (PBS), $\mathrm{pH}=8.3$, and inoculated on blood agar plates, which were incubated 24 hours at $37^{\circ} \mathrm{C}$. Growth of bacteria on the plates was assessed the next day and confirmed with $>300$ of bacterial colonies $(\mathrm{CFU} / \mathrm{mL})$ on a single plate.

\subsection{0\% NaOCl irrigation}

After incubation of biofilm teeth were rinsed with $3 \mathrm{~mL}$ of $5.20 \%$ $\mathrm{NaOCl}$ and then with $2 \mathrm{~mL}$ of $10 \mathrm{X}$ PBS with fetal bovine serum (FBS) for neutralization of $\mathrm{NaOCl}$ on cells. We collected $5 \mathrm{~mL}$ of suspension, of which $500 \mu \mathrm{L}$ was pipetted to prepare a sample for measuring cell viability on the flow cytometer.

\section{Er:YAG laser radiation}

Laser application was performed using Er:YAG laser TwinLight $\AA$ Endodontic Treatment (Fotona, Slovenia). We used the following characteristics; $2940 \mathrm{~nm}$ with pulse activated radiation, power output $15 \mathrm{~W}$, $20 \mathrm{~Hz}$, pulsing rate of $50 \mu \mathrm{s}, 1500 \mathrm{~mJ}$. The laser beam was completely inserted into root canal with optical conical fibre tip of $200 \mu \mathrm{m}$ and then laser radiation for 30 or 90 seconds was performed. After laser application we rinsed root canals with $3 \mathrm{~mL}$ of $1 \mathrm{x}$ PBS with $1 \mathrm{mM}$ EDTA, $\mathrm{pH}$ 8.3. We collected $3 \mathrm{~mL}$ of washed cell solution, which was used for flow cytometer analysis.

\section{Combination of Er:YAG laser and $\mathrm{NaOCl}$ irrigation}

Combined methodology, laser with $\mathrm{NaOCl}$ irrigation, consisted of the treatment processes using the power of the Er:YAG laser in the canal for 10 seconds and then the canals were irrigated with $1 \mathrm{~mL}$ of $5.20 \% \mathrm{NaOCl}$ for 10 seconds. After procedure rinsing of biofilm from the root canals with $2 \mathrm{~mL}$ of $1 \mathrm{x}$ PBS with $1 \mathrm{mM}$ EDTA, pH 8.3 was applied. $3 \mathrm{~mL}$ of rinsed solution was collected. 
Flow cytometry

After application of treatment methods, we obtained cell suspensions and have subtracted $500 \mu \mathrm{L}$ of suspension for analyses on the flow cytometer. To assure viability, we used "The Cell Viability Kit with Liquid Countailing Beads" (BD Biosciences). The assay includes the use of a pair of fluorescent dyes TO and PI. The dye TO enters the living as well as dead cells, but to varying degrees. The living cell membrane is impermeable to PI, which can enter only cells with damaged membrane (necrotic cells). The combination of these dyes allows the flow cytometer to differ between live and dead cells and thus establish their viability. We proceeded according to the manufacturer's instructions. $500 \mu \mathrm{L}$ of suspension was placed in a test tube for a cytometer. To the pipetted suspension $5 \mu \mathrm{L}$ of TO dye and $5 \mu \mathrm{L}$ of PI dye were added, and addtionly $50 \mu \mathrm{L}$ of BD Liquid Counting Beads. The test tube was well stirred and followed incubation for 10 minutes at room temperature and in darkness. After incubation, the sample was analyzed on the flow cytometer BD FACSCanto II.

\section{Positive control group}

Positive controls determined successful growth of microbial biofilm. Inoculated root canals were washed with $5 \mathrm{~mL}$ of $1 \mathrm{X}$ PBS with $1 \mathrm{mM} 17 \%$ EDTA. From the $5 \mathrm{~mL}$ we collected $500 \mu \mathrm{L}$ of suspension for the flow cytometry analysis and $100 \mu \mathrm{L}$ for inoculation on the blood agar. The plates were incubated for 24 hours at $37^{\circ} \mathrm{C}$ in an anaerobic atmosphere, and the next day the CFU - colony forming units were evaluated. Successful growth was estimated as the number of $>300 \mathrm{CFU} / \mathrm{mL}$.

\section{Statistical analysis}

Statistical software SPSS 20 (IBM, New York, USA) was used for statistical analyses. Two-Way ANOVA with post-hoc Tukey test were used with the percentage of dead microbial cells as dependent variables. Statistical significance was set at $\mathrm{p}$ value of $<0.05$.

\section{Results}

Table 1 represents results of laser application and irrigation with $5.20 \% \mathrm{NaOCl}$ on infected root canals. Results are presented as average percentage of dead cells that were detected by flow cytometer. Combination of two treatment methods (irrigation with $\mathrm{NaOCl}$ and laser application) showed the best disinfection efficacy and highest percent of dead microbial cells. 
Table 1: Dead microbial cells from infected root canals after application of Er:YAG laser and irrigation with $5.20 \% \mathrm{NaOCl}$ measured by flow cytometry.

\begin{tabular}{|c|c|c|c|c|c|}
\hline & \multicolumn{4}{|c|}{$\%$ of dead microbial cells detected by flow cytometry } & \multirow[b]{2}{*}{$\begin{array}{c}p- \\
\text { value }\end{array}$} \\
\hline & $\begin{array}{c}\text { Enterococcus } \\
\text { faecalis } \\
(\mathrm{N}=35)\end{array}$ & $\begin{array}{c}\text { Candida } \\
\text { albicans } \\
(\mathrm{N}=35)\end{array}$ & $\begin{array}{c}\text { Streptococcus } \\
\text { sanguinis } \\
(\mathrm{N}=35)\end{array}$ & $\begin{array}{c}\text { Fusebacterium } \\
\text { nucleatum } \\
(\mathrm{N}=35)\end{array}$ & \\
\hline Er:YAG & & & & & \\
\hline $30 \sec (\mathrm{N}=5)$ & 74,48 & 79,02 & 82,19 & 72,46 & 0,049 \\
\hline $90 \sec (\mathrm{N}=5)$ & 80,47 & 89,09 & 88,38 & 78,18 & 0,034 \\
\hline $\begin{array}{c}5,20 \% \text { NaOCl } \\
(\mathrm{N}=5)\end{array}$ & 59,54 & 66,57 & 72,22 & 72,61 & 0,022 \\
\hline Er:YAG+NaOC & & & & & \\
\hline $30 \sec (\mathrm{N}=5)$ & 81,15 & 84,63 & 94,76 & 80,04 & 0,041 \\
\hline $90 \sec (\mathrm{N}=5)$ & 90,35 & 92,47 & 92,81 & 89,35 & 0,152 \\
\hline p-value & $<0,001$ & $<0,001$ & $<0,001$ & $<0,001$ & \\
\hline $\begin{array}{l}\text { Positive control } \\
\qquad(\mathrm{N}=5) \\
\text { Negative control }\end{array}$ & 38,80 & 36,46 & 35,54 & 33,59 & 0,741 \\
\hline$(\mathrm{N}=5)$ & 0 & 0 & 0 & 0 & I \\
\hline
\end{tabular}

Positive controls were not treated with any method and showed more than $30 \%$ of dead microbial cells. Negative controls presented empty samples with no microbial cells.

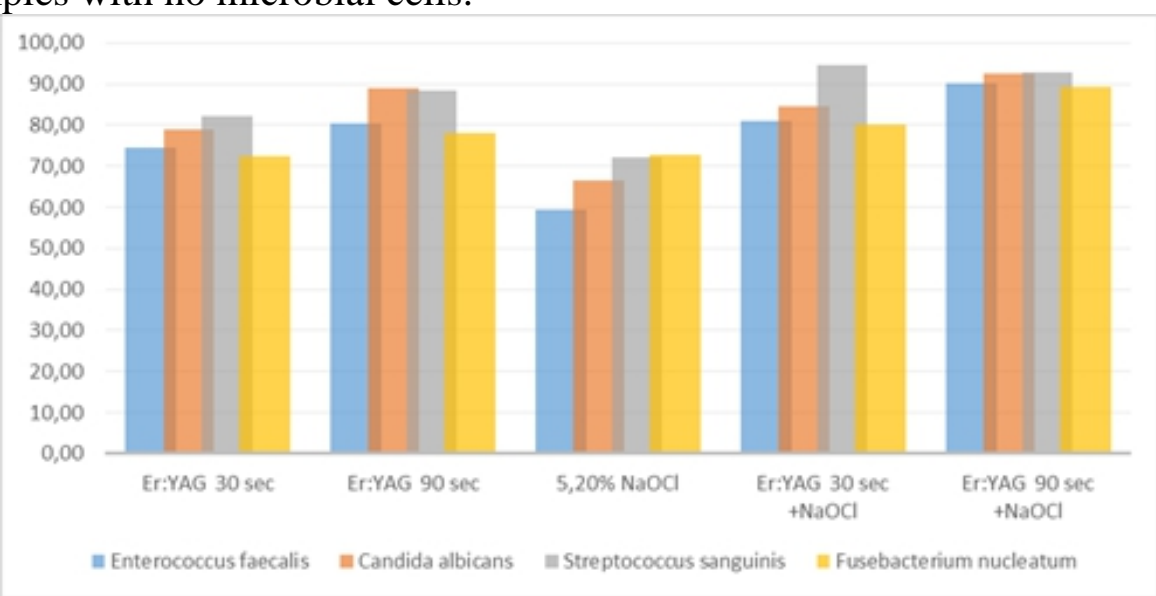

Figure 1: Antibacterial efficacy of disinfecting methods on microorganisms inoculated in the root canals.

Statistical analyses showed differences in number of dead microbial cells for laser radiations (30 and $90 \mathrm{sec}$ ) and for irrigation with 5.20\% $\mathrm{NaOCl}$. There were also statistically significant differences between treatment methods $(\mathrm{p}<0.001)$ for all microorganisms, as well as in interaction between organisms and treatment methods $(\mathrm{p}=0.040)$.

Number of dead $C$. albicans and $S$. sanguinis were significantly higher compared to $E$. faecalis or $F$. nucleatum for both treatment methods 
(Figure 1). However, combination of laser radiation and $\mathrm{NaOCl}$ irrigation was even more effective $(\mathrm{p}<0.001)$ in eliminating bacterial cells. While lower percent of dead cells was detected in the group with 30-second laser radiaiton, longer duration of laser radiation showed better disinfecting action. 90 -second irradiation was statistically significant compared to 30-second irradiation $(\mathrm{p}<0.001)$ and achieved over $80 \%$ of dead cells. Disinfecting activity in combination with irrigant was over $90 \%$ for addition of $\mathrm{NaOCl}$.

Values of dead microbial cells were comparable for E. faecalis and $F$. nucleatum and for $C$. albicans with $S$. sangunis. Values proved that laser radiation had the best disinfecting efficacy for all tested microorganisms $(\mathrm{p}<0.001$, respectively) and fewer bacterial cells were killed in the standard method of irrigation with $\mathrm{NaOCl}$. Meanwhile, combination of laser irradiation and $\mathrm{NaOCl}$ irrigation came close to total elimination of cells.

\section{Discussion}

Standard irrigations and instrumentation techniques in endodontics for cleaning infected root canal do not completely remove pathogens due to complex anatomy of the root canals. Beside that microorganisms can form biofilms and penetrate into the dentin tubules, hardly for standard methods to handle all microbial cells. The aim of our study was to establish the disinfecting efficiency of Er:YAG laser as antibacterial method for treatment of infected root canals.

We have proved that laser and $\mathrm{NaOCl}$ irrigation treatment methods successfully eliminated majority of microbial cells when compared to control groups. Radiation with Er:YAG laser showed higher percent of dead microbial cells compared to irrigation with 5.20\% NaOCl. Furthermore, with prolonged irradiation of 90 seconds we have observed even better disinfection efficacy. Additional 5\% of microbial cells were killed due to prolonged radiation. Interestingly, the lowest percentage of dead cells was recorded for $F$. nucelatum and E. faecalis, what proved that these bacteria are very persistant in root canals.

Standard endodontic irrigation with $\mathrm{NaOCl}$ is most widely used irrigant, but there still is no obvious agreement about its optimal concentration (Zehnder, 2006). Exposure to high concentrations of $\mathrm{NaOCl}$ was proved to be the most predictable method for eliminating intracanal bacterial biofilm (Clegg et al., 2006). According to our knowledge, 5.20\% $\mathrm{NaOCl}$ proved to be an effective irrigant. However, $\mathrm{NaOCl}$ is also toxic and may cause irritation to human gums, and at the end is still unable to completely remove the smear layer. We activated $5.20 \% \mathrm{NaOCl}$ via the Er:YAG laser radiation, and found even greater reduction in living bacterial cells compared to irrigation alone. The percent of dead microbial cells elevated over $90 \%$. 
Despite good study design both treatments could not remove all bactraial cells. Combination of laser radiation and irrigation with $\mathrm{NaOCl}$ came close to total elimination. We also proved that longer time of exposure resulted to more dead bacteria shorter time of exposure, we achieved over $80 \%$ of dead cells. Disinfecting activity in combination with irrigant was over $90 \%$ for addition of $\mathrm{NaOCl}$. The reason could be, that since Er:YAG laser effectively eluted smear layer and then killed bacteria, moreover irrigation with $\mathrm{NaOCl}$ eliminated the rest of viable cells, that were not harmed by laser radiation. The existing smear layer from root canals reduces the effectiveness of disinfecting agents, as intracanal bacteria form very tough biofilms. Irrigating solutions containing $\mathrm{NaOCl}$ could not alone show high antibacterial activity. The combination of two treatment methods expectedly achieved more than $90 \%$ reduction of viable bacterial cells. The efficiency of laser radiation could not only be explained by the increased consumption of available chlorine ions that occurred after the activation of the irrigant by an Er:YAG laser (Macedo et al., 2010), but might be related to the lysing and mechanical breaking of bacterial biofilm, after which irrigation with $\mathrm{NaOCl}$ killed most of free bacteria (DiVito et al., 2012; Peters et al., 2011). The results of our study were similar to other ex vivo studies, which confirmed that Er:YAG laser is the most appropriate laser for removal of intracanal smear layers (Schoop et al., 2007; Matsumoto et al., 2011; Blanken et al., 2009; De Moor et al., 2010; George \& Walsh., 2010; Benedicenti et al., 2008; Jaramillo et al., 2012). Laser radiation as treatment delivers a non-contact heating effect on the targeted surface. Heat and laser light are major advantages in disinfection process, because they can penetrate area of root canals where rinsing solutions have no access, and therefore eliminate microorganisms (Dostalova et al., 2002; Schoop et al., 2004; Perin et al., 2004; Gordon et al., 2007). When Er:YAG is used as an adjuvant therapy in combination with $\mathrm{NaOCl}$ in canals, better results were obtained (Schoop et al., 2004; Perin et al., 2004; Shahabi \& Zendedel, 2010). Our results suggest that the Er:YAG laser may be a valuable tool for root canal disinfection, due to it's ability to achieve significant disinfection of infected root canals for which there is evidence that conventional method is not as effective.

While our results did not show complete elimination of bacteria from the infected root canals, our design did quantify the percent of dead bacterial load after laser treatment. We achieved over $90 \%$ of reduction in viable bacteria using the combination of laser radiation and irrigation with $5.20 \%$ $\mathrm{NaOCl}$. Despite good performance in removing microbial biofilm after common disinfecting irrigation procedures, the use of additional modern techniques, such as lasers radiation, may be useful during endodontic treatment. However, future studies should evaluate the use and effectiveness 
of this methodology in clinical trials. Considering that endodontic infections are polymicrobial diseases, evaluating disinfection against only one organism represented a limitation in current study, since the presence of multiple microorganisms might have altered the dynamics demonstrated by the present study.

\section{Conclusion}

Er:YAG laser appeared to be an effective in enhancing the efficacy of $\mathrm{NaOCl}$ irrigation that is commonly used in endodontics. Both methods successfully killed microbial cells in the infected root canals, but none achieved $100 \%$ of dead microbial cells. Longer laser radiation showed better disinfection and achieved an average above $80 \%$ removal of the microorganism, shorter radiation only approximately $70 \%$. Only combination of two methods; irrigation with $5.20 \% \mathrm{NaOCl}$ and radiation with Er:YAG was effective in eradicating $90 \%$ of bacteria. The combined use of different methods is therefore necessary to enhance antimicrobial effectiveness.

\section{References:}

1. Aoki, A., Sasaki, K. M., Watanabe, H., \& Ishikawa, I. (2000). Lasers in nonsurgical periodontal therapy. Periodontology, 36(1), 59-97.

2. Benedicenti, S., Cassanelli, C., Signore, A., Ravera, G., \& Angiero, F. (2008). Decontamination of root canals with the galliumaluminum-arsenide laser: an in vitro study. Photomedicine and Laser Surgery, 26(4), 367-370.

3. Blanken, J., De Moor, R. J., Meire, M., \& Verdaasdonk, R. (2009). Laser induced explosive vapor and cavitation resulting in effective irrigation of the root canal, part 1: a visualization study. Lasers in Surgical Medicine, 41(7), 514-519.

4. Clegg, M. S., Vertucci, F. J., Walker, C., Belanger, M., \& Britto, L. R. (2006). The effect of exposure to irrigant solutions on apical dentin biofilms in vitro. Journal of Endodontics, 32, 434-437.

5. De Meyer, S., Meire, M. A., Coenye, T., \& De Moor, R. (2016). Effect of laser-activated irrigation on biofilms in artificial root canals. International Endodontic Journal, 50(5), 472-479.

6. De Moor, R. J., Meire, M., Goharkhay, K., Moritz, A., \& Vanobbergen, J. (2010). Efficacy of ultrasonic versus laser-activated irrigation to remove artificially placed dentin debris plugs. Journal of Endodontics, 36(9), 1580-1583.

7. DiVito, E., Peters, O. A., Olivi, G. (2012). Effectiveness of the erbium:YAG laser and new design radial and stripped tips in 
removing the smear layer after root canal instrumentation. Lasers in Medical Science, 27(2), 273-280.

8. Dostalova, T., Jelinkova, H., Housova, D., Sulc, J., Nemec, M., Duskova, J., Miyagi, M., \& Kratky, M. (2002). Endodontic treatment with application of Er:YAG laser waveguide radiation disinfection. Journal of Clinical Laser Medicine \& Surgery, 20(3), 135-139.

9. George, R., \& Walsh, L. J. (2010). Thermal effects from modified endodontic laser tips used in the apical third of root canals with erbium-doped yttrium aluminium garnet and erbium, chromiumdoped yttrium scandium gallium garnet lasers. Photomedicine and Laser Surgery, 28(2), 161-165.

10. Gordon, W., Atabakhsh, V. A., Meza, F., Doms, A., Nissan, R., Rizoiu, I., \& Stevens, R. H. (2007). The antimicrobial efficacy of the erbium, chromium:yttrium-scandium-gallium-garnet laser with radial emitting tips on root canal dentin walls infected with Enterococcus faecalis. Journal of American Dental Association, 138(7), 992-1002.

11. Gründling, G. L., Zechin, J. G., Jardim, W. M., Dias de Oliveira, S., \& Poli de Figueiredo, J. A. (2011). Effect of ultrasonics on Enterococcus faecalis biofilm in a bovine tooth model. Journal of Endodontics, 37(8), 1128-1133.

12. Ishikawa, I., Aoki, A., \& Takasaki, A. A. (2004). Potential applications of Erbium:YAG laser in periodontics. Journal of Periodontal Research, 39(4), 275-285.

13. Jaramillo, D. E., Aprecio, R. M., Angelov, N., DiVito, E., \& McClammy, T. V. (2012). Efficacy of photon induced photoacoustic streaming (PIPS) on root canals infected with Enterococcus faecalis: a pilot study. Endodontic Practice, 5(3), 28-32.

14. Macedo, R. G., Wesselink, P. R., Zaccheo, F., Fanali, D., \& Van Der Sluis, L. W. (2010). Reaction rate of $\mathrm{NaOCl}$ in contact with bovine dentine: effect of activation, exposure time, concentration and $\mathrm{pH}$. International Endodontic Journal, 43(12), 1108-1115.

15. Matsumoto, H., Yoshimine, Y., \& Akamine, A. (2011). Visualization of irrigant flow and cavitation induced by Er:YAG laser within a root canal model. Journal of Endodontics, 37(6), 839-843.

16. Ng, R., Singh, F., Papamanou, D. A., Song, X., Patel, C., Holewa, C., Patel, N., Klepac-Ceraj, V., Fontana C. R., Kent, R., Pagonis, T. C., Stashenko P. P., \& Soukos N. S. (2011). Endodontic photodynamic therapy ex vivo. Journal of Endodontics, 37(2), 217-222.

17. Perin, F. M., França, S. C., Silva-Sousa, Y. T., Alfredo, E., Saquy, P. C., Estrela, C., \& Sousa-Neto, M. D. (2004). Evaluation of the antimicrobial effect of Er:YAG laser irradiation versus $1 \%$ sodium 
hypochlorite irrigation for root canal disinfection. Australian Endodontic Journal, 30(1), 20-22.

18. Peters, O. A., Bardsley, S., Fong, J., Pandher, G., \& DiVito, E. (2011). Disinfection of root canals with photon-initiated photoacoustic streaming. Journal of Endodontics, 37(7), 1008-1012.

19. Schoop, U., Goharkhay, K., Klimscha, J., Zagler, M., Wernisch, J., Georgopoulos, A., Sperr, W., \& Moritz, A. (2007). The use of the Erbium, Chromium:Yttrium-Scandium-Gallium-Garnet laser in endodontic treatment: the results of an in vitro study. Journal of American Dental Association, 138(7), 949-955.

20. Schoop, U., Kluger, W., Moritz, A., Nedjelik, N., Georgopoulos, A., \& Sperr, W. (2004). Bactericidal effect of different laser systems in the deep layers of dentin. Lasers in Surgical Medicine, 35(2), 111116.

21. Schwarz, F., Aoki, A., Becker, J., \& Sculean, A. (2008). Laser application in non-surgical periodontal therapy: a systematic review. Journal of Clinical Periodontology, 35(8 Suppl), 29-44.

22. Sculean, A., Schwarz, F., Berakdar, M., Romanos, G. E., Arweiler, N. B., \& Becker, J. (2004). Periodontal treatment with an Er:YAG laser compared to ultrasonic instrumentation: a pilot study. Journal of Periodontology, 75(7), 966-973.

23. Shahabi, S., \& Zendedel, S. (2010). Atomic analysis and hardness measurement of the cavity prepared by laser. Lasers in Medical Science, 25(3), 379-383.

24. Soukos, N. S., Chen, P. S. Y., Morris, J. T., Ruggiero, K., Abernethy, A.D., Som, S., Foschi, F., Doucette, S., Bammann L. L., Fontana C. R., Doukas A. G., \& Stashenko P. P. (2006). Photodynamic therapy for endodontic disinfection. Journal of Endodontics, 32(10), 979-984.

25. Zehnder, M. (2006). Root canal irrigants. Journal of Endodontics, 32, 389-398. 